\title{
SPA Otel İşletmelerinin Çevrimiçi Müşteri Değerlendirmeleri: Tripadvisor Örneği (Online Customer Reviews for SPA Hotels: The Case of Tripadvisor)
}

\author{
Halide GERANAZ iD a Duygu YETGIN ${ }^{\text {iD }}$ b \\ a Anadolu Üniversitesi, Turizm İşletmeciliği Programı, Eskişehir, Türkiye. halidegeranaz@anadolu.edu.tr \\ b Anadolu Üniversitesi, Turizm Fakültesi, Turizm Rehberliği Bölümü, Eskişehir, Türkiye. dyetgin@anadolu.edu.tr
}

\section{Sağlık turizmi \\ Tripadvisor \\ SPA Otelleri \\ İçerik analizi \\ Sapanca}

MAKALE BİLGISI

Anahtar Kelimeler:

Gönderilme Tarihi 2 Temmuz 2021

Revizyon Tarihi 22 Eylül 2021

Kabul Tarihi 26 Eylül 2021

Makale Kategorisi:

Araştırma Makalesi

\section{ÖZET}

Amaç - Bu makalede Sapanca'da hizmet veren beş yıldızlı SPA otelleri hakkında konukların beklentilerinin ortaya çıkarılması ve SPA otellerinde memnuniyeti etkileyen faktörlerin belirlenmesi amaçlanmıştır.

Yöntem - Çalışmada nitel araştırma yöntemi kullanılmıştır.1 Nisan 2020-1 Nisan 2021 tarihleri arasında, Sapanca'da faaliyet gösteren beş yıldızlı SPA otellerine yönelik Tripadvisor.com web sitesinde yapılan toplam 485 olumlu ve olumsuz yorum incelenmiştir. Yorumlar içerik analizi yöntemi ile anlamlı bölümlere ayrılmış, dokuz ana tema ve 54 alt tema altında toplanmıştır.

Bulgular - Araştırma sonucunda yorumların sırasıyla "insan kaynakları" kategorisinde ilgili olma, "SPA" kategorisinde SPA hizmetlerinin başarılı olması, "yiyecek ve içecek" kategorisinde yemeklerin lezzetli olması konularında yoğunlaştığı saptanmıştır.

Tartışma - İnternetin gelişmesi ve yaygınlaşması ile çevrim içi müş̧eri yorumları turistler için önemli bir bilgi kaynağı haline gelmeye başlamıştır. Konukların işletme ile ilgili memnun oldukları ve olmadıkları noktaları göstermesi nedeniyle çevrim içi yorumlar işletmeler açısından da önem taşımaktadır. Literatürde Türkiye'de SPA otelleri özelinde çevrimiçi yorumları inceleyen bir araştırma bulunmamaktadır. Bu çalışma SPA otellerinde konukların yorumlarının incelenmesi ile konuk memnuniyetini en çok etkileyen faktörlerin insan kaynakları, SPA, yiyecek ve içecek olduğunu ortaya koymaktadır. Araştırma sonucunda SPA otellerinde SPA hizmetlerinin başarısının genel memnuniyet üzerinde önemli bir etkiye sahip olduğu görülmektedir. SPA ile ilgili yorumlarda havuzlarla ilgili yorumların öne çıkması havuzların çeşitliliğine ve temizliğine önem verilmesi gerektiğini göstermektedir. Ayrıca SPA hizmetlerinin başarılı yürütülmesi için yeterli sayıda personelin bulunması, özellikle SPAların ana hizmetlerinden biri olan masaj için profesyonel ve eğitimli personelin istihdam edilmesi önem taşımaktadır.

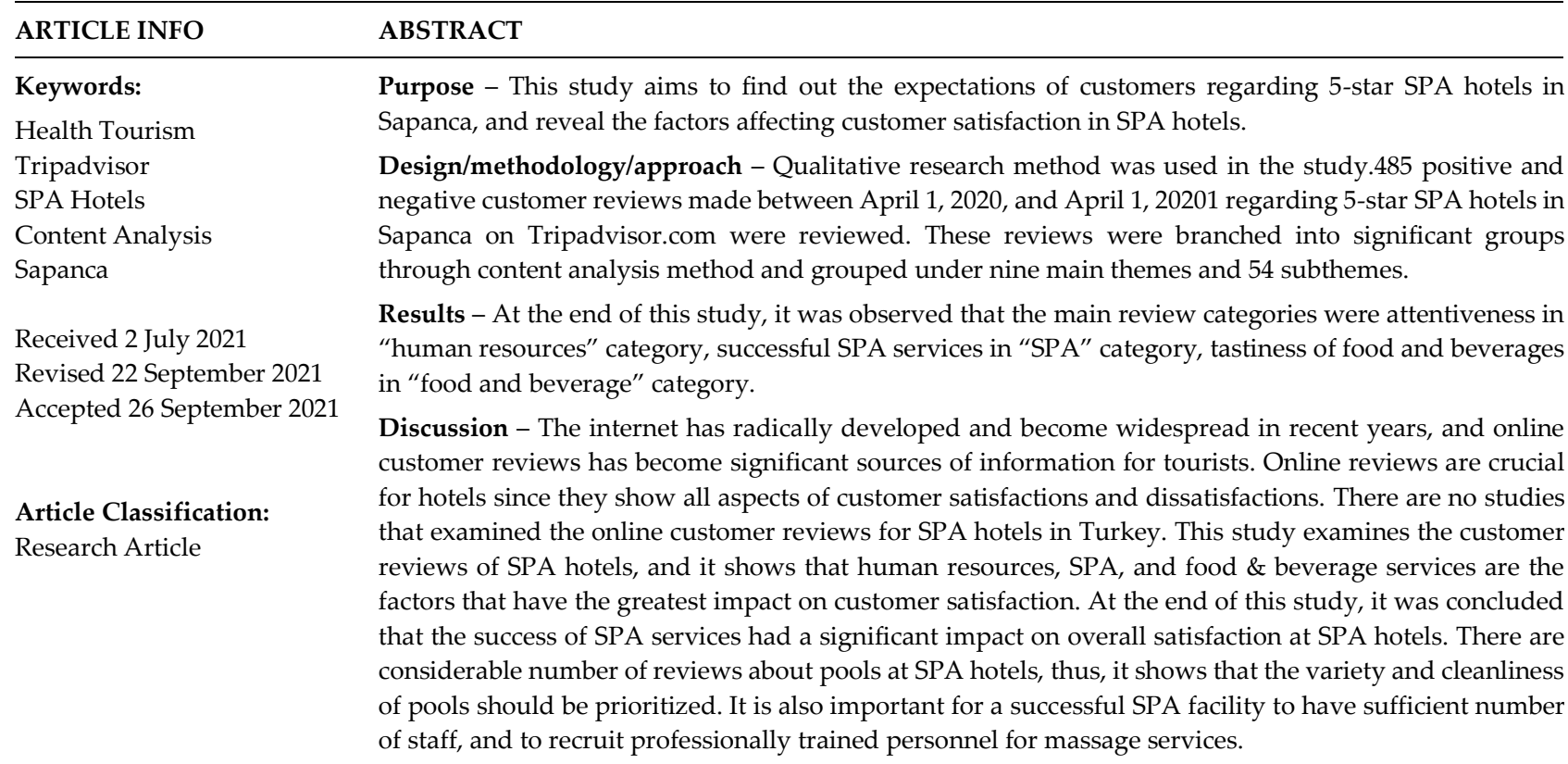




\section{GİRİS}

Turizm ürünleri soyuttur ve tüketim öncesi değerlendirme yapmak zordur. Soyutluk özelliği tüketiciler tarafından algılanan riski artırmaktadır. Bu riski azaltmak için tüketiciler karar verme sürecinde diğer tüketicilerin görüşlerine başvurmaktadır (Litvin vd., 2008:458; Kwon vd., 2011). Bu bağlamda e-WOM, tüketiciler için önemli bir bilgi kaynağı olarak görülmektedir (Reyes-Menendez vd., 2019: 68868). E-WOM kapsamında değerlendirilen çevrimiçi incelemeler her sektörde olduğu gibi turizmde de giderek yaygınlaşmaktadır. Turizm endüstrisinde, çevrimiçi incelemeler geleneksel ağızdan ağıza iletişimin elektronik versiyonları olarak kabul edilmekte ve gezginlerin deneyimledikleri turizm ürünleri, hizmetleri ve markaları hakkında yayınladıkları yorumlardan oluşmaktadır (Filieri ve McLea, 2014).

Günümüzde seyahat eden kişilerin yüzde 80'inden fazlasının kullandığı Tripadvisor gibi çevrim içi kanallar hem potansiyel turistler hem de işletmeler açısından önem taşımaktadır. Bu kanallar işletmeler için inceleme ve değerlendirme, potansiyel müşteriler için ise alternatifleri değerlendirerek seçimleri belirleme ve satın alınan hizmet sonrası deneyimleri aktarma gibi olanaklar sunmasıyla öne çıkmaktadır (Yılmaz, 2019:28). İnternet üzerinden yapılan yorumların dikkatle incelenmesi, şikayetlerin ve memnuniyetlerin yoğunlaştı̆̆ konuların tespit edilmesi konaklama işletmelerinin hizmet kalitesini artırması ve müşteri memnuniyetini sağlaması açısından büyük önem taşımaktadır.

Bu çalışmanın amacı, Sapanca'da SPA otellerini ziyaret eden konukların bu otellere yönelik beklentilerini ortaya koymaktır. Bu amaç doğrultusunda dünyanın en popüler ve en çok kullanıcı yorumu içeren seyahat sitesi olan Tripadvisor veri kaynağı olarak kullanılmıştır. Tripadvisor'da Sapanca'da bulunan 5 yıldızlı SPA otellerine yönelik yorumlar incelenerek olumlu ve olumsuz yorumların hangi kategoriler altında yoğunlaştı̆̆ 1 belirlenmiştir. Çalışma kapsamında Sapanca Bölgesi'ndeki SPA otellerinin seçilme nedeni, son birkaç yılda özellikle sonbahar ve kış döneminde çevrimiçi platformlarda bu otellere ilişkin paylaşımlar, tanıtımlar ve reklamların artmasıyla bu otellerin giderek daha popüler hale gelmesidir. İlgili literatürde Sapanca Bölgesi'ndeki SPA otellerinin incelendiği herhangi bir çalışma bulunmamaktadır. Bu nedenle çalışma literatür ve sektöre katkı sağlaması açısından önem taşımaktadır.

\section{KAVRAMSAL ÇERÇEVE}

\section{Sağlık Turizmi}

Günümüzde kronik hastalıkların oranları ile birlikte tedavi maliyetleri hızla artarken, insanların kaliteli sağlık hizmeti alma talebi de artış göstermektedir. Maliyetlerin ve katkı paylarının yüksek olduğu ülkelerdeki insanlar, sağlığını korumak ve sağlıklı yaşamı sürdürebilmek için kaliteli ve daha uygun maliyetle sağlık sorunları çözebilecekleri ülkelere yönelmektedir (Çelik, 2009). Bu durum sağlık turizminin ortaya çıkmasına neden olmuştur.

Sağlık turizmi, hastaların acil sağlık hizmetini ya da seçtikleri bir sağlık hizmetini farklı ülkelerden alması olarak tanımlamaktadır (Barca vd., 2013:66). Hastaların tedavi amaçlı sağlık turizmine katılmalarının pek çok sebebi bulunmaktadır. Uzun bekleme listeleri, ileri donanım ve teknolojiye sahip olan ülkede tedavi olma isteği, daha kaliteli sağlık hizmeti alma isteği, gelişmişülkelerde sağlık hizmetlerinin pahalı olması, bulunulan ülkede sağlık sisteminin yeterince gelişmiş olmaması ve sigorta ile ilgili sorunlar çıkması başlıca nedenler arasındadır (Tontuş, 2019).

\section{SPA Turizmi ve SPA Otelleri}

SPA kelimesinin kökenine dair dünyada farklı görüşler bulunmaktadır. Bu kelimenin Latince' de "sudan gelen sağlık" anlamına gelen "Salus Per Aquam" kelimelerinin kısaltması olduğu düşünülmektedir (Ergüven, 2010). Ayrıca bu kelimenin Belçika'nın Waloon Bölgesi'nde çeşme anlamına gelen "espa" kelimesinden türetildiği ya da Latince'de saçmak, serpmek, nemlendirmek anlamına gelen "spagere" kelimesinden türetildiği de yaygın görüşler arasındadır (Van Tubergen ve Van der Linden, 2002:273).

SPA kavramının içeriği ve anlamı geçmişten günümüze değişim göstermiştir. SPA'lar ilk zamanlarda "hastalıkları hafifletmeye veya iyileştirmeye yardımcı olan doğal kaplıcalara sahip yerler" olarak tanımlanmıştır. Zamanla bu tanım değişerek su yoluyla fiziksel, zihinsel ve duygusal rahatlama sağlayan yerler olmaya evrilmiştir. Günümüzde SPA terapileri sadece suyun rahatlatıcı ve iyileştirici etkilerini değil, 


\section{H. Geranaz - D. Yetgin 13/3 (2021) 2800-2818}

aynı zamanda masaj veya yoga gibi zihin, beden ve ruhun gevşemesini ve hafifletilmesini vurgulayan diğer terapi türlerini de içermektedir (Ramos, 2016).

Uluslararası SPA Birliği (ISPA) SPA'yı "çeşitli profesyonel hizmetler aracılığıyla zihnin, bedenin ve ruhun yenilenmesini teşvik eden genel esenliğe ayrılmış yerler" olarak tanımlamaktadır. SPA hizmet yelpazesinde, ıslak alanlar (banyolar), saunalar, kozmetik, masaj, fitness, beslenme danışmanlığı, solaryum gibi çeşitli hizmetler yer almaktadır. Bazı SPA'lar bu hizmetlerin tümüne yer verirken bazıları sadece belirli hizmet türlerinde yoğunlaşabilmektedir (Ergüven, 2020:18). 1991 yllında kurulan ve SPA endüstrisinin profesyonel organizasyonu ve sesi olarak bilinen Uluslararası Spa Birliği SPA'ları altı sınıfa ayırarak kategorize etmiştir. Bu sinıflar; kulüp SPA, günlük SPA, destinasyon SPA, mineral kaynak SPA, resort/otel SPA ve medikal SPA'dır (ISPA; Ergüven, 2020:18).

Türkiye' deki sağlık turizmine SPA ve wellness açısından bakıldığında; şehir otelleri, termal otel işletmeleri ile deniz-kum-güneş turizmine yönelik hizmet veren 4 ve 5 yıldızlı otel işletmelerinde SPA ve wellness bölümlerinin olduğu görülmektedir. Bu işletmelerin içinde yer alan SPA ve wellness bölümleri, diğer hizmetleri destekleyici bir ürün olarak görülebilir. Sapanca gibi destinasyonlarda ise SPA ve wellness turizmi önemli bir ürün ve hizmet yelpazesi sunmaktadır (Kaya ve Kalyoncu, 2020:192).

Araştırmamıza konu aldığımız tesisler, içerisinde SPA bulunduran 5 yıldızlı otellerdir. Bu bağlamda Resort/Otel SPA kategorisinde değerlendirilmektedirler. Günümüzde otelciler SPA'ların işletmelere getirebileceği faydaların farkına varmıştır. Böylece SPA'lar bir lüks olmaktan çıkıp neredeyse bir ihtiyaç olarak görülmeye başlamış, lüks otel ve tatil köylerinin standart bir özelliği haline gelmiştir (Thorsteinsdottir, 2005; Cohen, 2008). Konaklama tesisleri için iyi planlanmış bir SPA merkezi yalnızca gelire ve karlılığa doğrudan katkıda bulunmakla kalmamakta, aynı zamanda ortalama oda fiyatını artırıcı bir etki göstermekte ve mevsimsellik sorunlarının üstesinden gelmeye yardımcı olabilmektedir (Thorsteinsdottir, 2005:275).

Konaklama tesislerindeki deneyimler, bütüncül olarak ele alındığından SPA hizmetlerinin kalitesi konukların genel memnuniyetleri üzerinde önemli etkiye sahiptir. SPA hizmetlerinin kalitesini artırmak için talebin incelenmesi yani SPA'ya gidenlerin motivasyonlarının anlaşılması önem taşımaktadır. Mak vd. (2009) SPA tesislerini ziyaret eden turistlerin önemli motivasyonlarının rahatlama ve gevşeme, kaçış, kendini ödüllendirme, hoşgörü, sağlık ve güzellik olduğunu saptamıştır. Trihas ve Konstantarou (2016) stres atma ve rahatlamanın SPAları ziyaret etmede birinci neden olduğunu, ardından fiziksel sağlığı iyileştirme ve güzellik bakımları yaptırma motivasyonlarının geldiğini belirtmektedir. Rahatlama, gevşeme ve stres atmanın SPA'ları ziyaret etmede en önemli motivasyonlar olduğu görülmektedir.

\section{Elektronik ağızdan ağıza iletişim (e-WOM) ve konaklama işletmeleri için önemi}

Ağızdan ağıza iletişim (WOM), piyasaların sunduğu çeşitli mal ve hizmetler hakkında fikir alışverişinde bulunmanın muhtemelen en eski yoludur (Goyette vd., 2010:6). Genel anlamda ağızdan ağıza iletişim (WOM), mal veya hizmetlerin kullanımı, özellikleri veya bunların satıcıları ile ilgili tüm gayri resmi iletişim olarak tanımlanmaktadır (Westbrook, 1987). Günümüz tüketicileri her zamankinden daha zengin bilgi ortamlarıyla karşı karşıyadır (Lurie, 2004). Hızla gelişen teknolojiler ve internet'in yaygınlaşması nedeniyle, geleneksel ağızdan ağıza iletişim elektronik ağızdan ağıza iletişime (e-WOM) dönüşmüştür (Reyes-Menendez vd., 2019). E-WOM, bir ürün veya şirket hakkında potansiyel, gerçek veya eski müşteriler tarafından internet üzerinden yapılan, çok sayıda kişi ve kurumun erişebildiği olumlu veya olumsuz her türlü açılama olarak tanımlanmaktadır (Hennig-Thurau vd., 2004:39).

$\mathrm{Bu}$ araştırma kapsamında ele alınan çevrimiçi tüketici yorumları e-WOM kapsamında değerlendirilmektedir. Günümüzde birçok turist seyahat planlama aşamasında interneti kullanmakta ve çevrimiçi tüketici yorumlarını incelemektedir. Çevrimiçi sosyal seyahat ağları kullanıcıların oteller veya yerel turistik yerler hakkında etkileşimde bulunmalarına ve incelemeler yapmalarına olanak tanımaktadır (Miguéns vd., 2009; Sevinç, 2021). Çevrimiçi incelemeler turistlerin otel seçiminde rol oynamakta ve olumlu yorumlar kişilerin rezervasyon yapma niyetini artırmaktadır (Vermeulen ve Seegers, 2009; Sparks ve Browning, 2011).

e-WOM sadece tüketici adayları için değil yoruma konu olan ürün ve üreticiler açısından da önemlidir, çünkü işletmeler olumlu ve olumsuz yorumları gözeterek stratejilerine karar verebilmektedir (Sarışık ve Özbay, 2012:17). Bu bağlamda çevrimiçi tüketici yorumları içeren seyahat siteleri hem potansiyel turistler hem de işletmeciler için iyi bir bilgi kaynağı olmasıyla önem taşımaktadır. 


\section{Literatür Taraması}

Konaklama işletmelerinde çevrim içi müşteri değerlendirmelerine yönelik yapılan çalışmalar incelendiğinde literatürde konuyu farklı açılardan ele alan çok sayıda çalışma olduğu görülmektedir. Stringam ve Gerdes (2019) hangi faktörlerin puanlamayı etkilediğini belirlemek için 60.000'den fazla yorumu kelime sıklığ 1 analizi ile incelemiştir. Gezginlerin en çok otelin kirli olması, banyo ve yataklar konusunda endişe duyduklarını, yüksek puanlı yorumlarda otelin turistik mekanlara, alışveriş yerlerine, havaalanlarına ve şehir merkezine yakınlığından ve yiyecek-içecek hizmetlerinden bahsedildiğini saptamışlardır. Berezina vd. (2016) otel işletmelerinden memnun olan ve memnun olmayan konukların çevrimiçi yorumlarını karşılaştırmıştır. Araştırma sonuçları oteli tavsiye etmeye istekli olan memnun müşterilerin, memnun olmayan müşterilere kıyasla, "personel" gibi otelin soyut yönlerine atıfta bulunduğunu, memnun olmayan müşterilerin ise mobilyalar ve ücretler gibi somut kısımlara odaklandığını göstermektedir.

Snehasish ve Chua (2016) Tripadvisor puanlamalarının zincir ve bağımsız otellere göre nasıl farklılık gösterdiğini araştırmıştır. Oteller coğrafi bölgelere göre, gezginler ise profillerine göre gruplanmıştır. Gezginlerin puanlandırma kalıplarının hem profiller hem de bölgelere göre bağımsız ve zincir oteller arasında önemli ölçüde farklılık gösterdiği saptanmıştır. Limberger vd. (2014) Brezilya'daki otellerin Tripadvisor yorumların incelemiş; oda, sağlanan hizmet ve maliyet-fayda kriterleri ile genel memnuniyet arasında güçlü bir ilişki olduğu sonucuna ulaşmıştır. Barreda ve Bilgihan (2013) 3,124 otelin çevrim içi yorumlarını incelemiş, gezginlerin temel endişesinin temizlik olduğunu, ilgi çekici yerler, alışveriş, havaalanları ve restoranlar gibi iyi alanlara elverişli konumu olan oteller hakkında ise olumlu yorumlar yazma olasılıklarının daha yüksek olduğu saptamıştır. Ayrıca güler yüzlü ve iyi eğitimli bir personelden alınan hizmetin kalitesinin gezgin görüşlerini olumlu etkilediği belirtilmiştir. Li vd. (2013) ise çevrim içi yorumları lüks oteller ve ekonomik oteller bazında incelemiştir. Ulaşım kolaylığı, yiyecek ve içecek yönetimi, turistik yerlere yakınlık ve paranın karşılığını alma faktörlerinin hem lüks hem de ekonomik otel rezervasyonu yapan müşteriler için önemli olduğunu ve performansı etkilediğini belirlemiştir. Müşterilerin, yatak, resepsiyon hizmetleri, oda büyüklüğü ve dekorasyonu faktörlerine önem verdiği ancak bunlardan memnun olma derecelerinin düşük olduğu sonucuna ulaşmışlardır. O'Connor (2010) Tripadvisor.com sitesinde otellerin eleştirilere cevap verme imkânı olduğu halde çok az işletmenin bunu kullandığını, kullanıcı tarafından üretilen içerikleri yeterince dikkate almadığı sonucuna ulaşmıştır.

Ulusal literatürde yapılan çalışmalara bakıldığında, Gürbüz ve Ormankıran (2020) Belek Bölgesi'nde faaliyet gösteren, Tripadvisor.com'da ilk 50'de yer alan otel işletmelerinin yorumlarını incelemiş hem pozitif yorumların hem de şikayetlerin personel davranışı ve yeme-içme konularında yoğunlaştığını saptamıştır. Yeşilyurt vd. (2020) Adıyaman'daki otel işletmelerinin Tripadvisor yorumlarını incelemiş, en fazla şikâyetin yiyecek-içecek temasında olduğunu belirlemiştir. Şahin vd. (2020) Kuşadası'nda bulunan 5 yıldızlı oteller ile ilgili Tripadvisor yorumlarını incelmiş, yorumların büyük çoğunluğunun personel ve yemekler üzerinde olduğunu belirlemiştir. Çoban vd. (2019) Eskişehir'de faaliyet gösteren şehir otellerinin Tripadvisor yorumlarını incelemiş, yorumların insan kaynakları temasında personelin güler yüzlü olması, yiyecek ve içecek temasında kahvaltı/yemeğin lezzetli olması, kat hizmetleri temasında ise odaların temiz olması konularında yoğunlaştığı sonucuna ulaşmıştır. Sezen Doğancili vd. (2018) Göller Yöresi'nde yer alan konaklama işletmelerinin Tripadvisor yorumlarında en çok ele alınan olumlu unsurların personel, temizlik ve yemek olduğunu saptamıştır. Bayram (2018) Tripadvisor tarafından ilan edilen Dünya genelindeki en iyi on otel işletmesine ait konuk yorumlarını incelemiş, oda ve çalışan gibi unsurların yanında fark yaratan tematik hizmetler, karşılama, ikram ve beklentileri aşmak gibi unsurların müşteri memnuniyetini oluşturduğunu belirtmiştir. Çuhadar vd. (2018) Isparta il sınırları içerisinde faaliyet gösteren 21 otel ve 9 pansiyonu kapsayan çalışmalarında, konaklama tesisinin türü, hukuki durumu, fiyatı ve konumu ile müşterilerin değerlendirme skoru arasında bir ilişki olup olmadığını araştırmıştır. Konaklama işletmelerinin türü ile çevrimiçi müşteri skorları arasında istatistiksel olarak anlamlı farklılı̆ıın olduğunu ancak diğer kriterlerde anlamlı farklılık görülmediğini saptamışlardır. Bertan vd. (2015) termal otellerin Tripadvisor yorumlarını incelemiştir. En önemli faktörün otellerin temizliği olduğunu, bunu konum, uyku kalitesi, odalar ve hizmetin izlediğini saptamıştır. Kızılırmak vd. (2014) Doğu Karadeniz Bölgesi'ndeki otellerin Tripadvisor yorumlarını genel memnuniyet, yorum yapanların sosyo-demografik profili ve işletmelerin yorumlara dönüş oranı açısından incelemiş, konukların genel olarak olumlu deneyim yaşadıklarını ancak konaklama işletmelerinin yorumlara geri dönme oranının düşük olduğunu (\%10,4) saptamışlardır. Bayram vd. (2014) Pamukkale ve Karahayıt 


\section{H. Geranaz - D. Yetgin 13/3 (2021) 2800-2818}

destinasyonlarında bulunan konaklama tesislerine ait Tripadvisor yorumlarını incelemiş, tesislerin konumu ve temizliğinin turistler tarafından en beğenilen özellikler olduğunu saptamıştır.

Ulusal literatürde çeşitli bölgelerde otellerin çevrim içi yorumlarının incelendiği çalışmalar bulunmaktadır; ancak SPA otelleri özelinde herhangi bir çalışmaya rastlanmamışır. Bu çalışma ile literatürdeki bu boşluk doldurularak, konukların SPA otelleri ile ilgili memnuniyet ve beklentileri ortaya çıkarılacaktır.

\section{YÖNTEM}

Bu çalışma Sapanca'da hizmet veren beş yıldızlı SPA otelleri hakkında konukların beklentilerini ortaya çıkararak SPA otellerinde memnuniyeti etkileyen faktörlerin belirlenmesini amaçlamaktadır. Bu amaç doğrultusunda nitel araştırma yöntemi kullanılarak, Sapanca' da faaliyet gösteren 5 yıldızlı SPA otellerine dair Tripadvisor.com sitesinde yer alan olumlu ve olumsuz yorumlar incelenmiştir. Bu doğrultuda Tripadvisor.com sitesinde yer alan beş yıldızlı SPA otelleri için 1 Nisan 2020-1 Nisan 2021 arasında yapılan toplam 485 yorum ele alınmıştır. İncelenen yorumlarda birden fazla temanın aynı anda ele alınması nedeniyle kod sayısı 1795'e yükselmiştir.

Veri kaynağı olarak Tripadvisor.com sitesinin seçilme nedeni dünya çapında seyahat ve turizm alanında en çok ziyaret edilen web sitesi olmasıdır. 2020 itibariyle Tripadvisor'da yaklaşık 884 milyon yorum vardır (Statista, 2021). Günümüzde sosyal medyanın kullanım alanları giderek genişlemektedir. Turistik destinasyonlar ve turizm işletmeleri sosyal medyayı pazarlama ve tanıtım faaliyetlerini gerçekleştirmek amacıyla kullanmaktadır. Ayrıca gezgin bireylerin sosyal medya üzerinden yaptığı paylaşımların diğer kullanıcıları etkilediği görülmektedir (Hamzaçebi ve Yozgat, 2019:62). Son birkaç yılda sonbahar ve kış döneminde Sapanca'da sosyal medya fenomenlerinin SPA otelleri ile ilgili paylaşımlarının artmasıyla ve otellerin kendi sosyal medya hesaplarından daha yoğun şekilde tanıtım yapmaya başlamasıyla SPA otelleri daha büyük bir kitle tarafından bilinir hale gelmiştir. Tüm bu nedenlerle ziyaretçi sayısındaki artışa bağlı olarak daha kapsamlı sonuçlar elde edilebileceği düşünüldüğü için bu tarih aralığından bir kesim olan son bir yılın verilerinin incelenmesi tercih edilmiştir. Ayrıca COVID-19 pandemisinin turistlerin otel beklentilerinde ne gibi değişikliklere yol açacağı konusunda bilgi vermesi de tercih nedenlerinden biridir.

Tripadvisor.com sitesinden elde edilen veriler içerik analizi kullanılarak incelenmiştir. İçerik analizi, verilerin belirli temalar ve kavramlar çerçevesinde bir araya getirilerek düzenlendiği bir araştırma yöntemidir (Gürbüz ve Şahin, 2018:413). Bu analiz ile kategoriler oluşturulur ve bu kategorilerdeki örneklerin sayısı/sıklığ1 belirlenir (Joffe ve Yardley, 2004). Verilerin kodlanması, temaların bulunması, kodların ve temaların düzenlenmesi, bulguların tanımlanması ve yorumlanması olmak üzere dört aşamalı bir süreçten oluşmaktadır. Kodlama aşamasında veriler anlamlı bölümlere ayrılır ve her bir bölümün kavramsal olarak ne ifade ettiği belirlenir. Sonrasında elde edilen kodlar bir araya getirilerek ortak yönler bulunur ve kodları genel düzeyde açıklayıp kategoriler altında toplayabilen temalar geliştirilir. Temaların da tanımlanmasıyla veriler kodlar ve temalara göre sistematik bir şekilde düzenlenir, bulgular ayrıntılı bir şekilde sunulur. En son adımda ise sunulan bulgular araştırmacı tarafından yorumlanır (Yıldırım ve Şimşek, 2018:243).

Lincoln ve Guba (1985) araştırmalarda güvenirliği sağlamak için geçerlik, dış geçerlik, güvenirlik ve objektiflik terimleri yerine inandırıcılık, güvenilebilirlik, onaylanabilirlik, aktarılabilirlik, tutarlılık, özgünlük gibi terimleri kullanmıştır. Günümüzde nitel araştırmalarda Lincoln ve Guba'nın kriterleri yoğun olarak kullanılmaktadır (Creswell, 2013:246). Bu araştırmada inandırıcılık ve tutarlılı̆̆ sağlamak için iki uzmanın görüşünden faydalanılmıştır. Uzman incelemesi konu hakkında uzman olan bir araştırmacının, araştırma deseninin belirlenmesi, verilerin toplanması, analizi, sonuçların yazımı gibi süreçleri eleştirel bir bakış açısıyla incelediği ve geri bildirimlerde bulunduğu yöntemdir (Başkale, 2016:24).

Onaylanabilirlik kriterini sağlamak için araştırmacı önyargılarını azaltmanın ve çoklu bakış açıları sağlamanın bir yolu, üçgenleme içeren yöntemleri kullanmaktır. Bu araştırmada güvenilebilirliği sağlamak için üçgenleme yöntemi tercih edilmiştir. Üçgenleme, iki veya daha fazla veri kaynağının, araştırmacıların, metodolojik yaklaşımın, teorik perspektifin aynı çalışmada kullanılmasıdır. Veri üçgenlemesi, araştırmacı üçgenlemesi, metodolojik üçgenleme ve teorik üçgenleme gibi farklı çeşitlerde yapılabilmektedir. Nitel veya nicel araştırma olması fark etmeksizin, verilerin birden fazla araştırmacı tarafından yorumlanması, çapraz kontrol edilmesi ve doğrulanması bulguların değerini artırmaktadır (Thurmond, 2001:254). Bu araştırmada araştırmacı üçgenlemesi yöntemi tercih edilerek iki araştırmacı çalışmayı birlikte yürütmüştür. 


\section{BULGULAR}

Tripadvisor.com sitesinden elde edilen veriler incelenerek anlamlı bölümlere ayrılmış, aralarındaki ortak yönler saptanarak ana temalar ve alt temalar belirlenmiştir. Bu bağlamda veriler odaların fiziksel özellikleri, otelin imkanları, otelin konumu, yiyecek ve içecek, SPA, insan kaynakları, kat hizmetleri, otelin özellikleri ve fiyatlar olmak üzere dokuz ana tema ve 54 alt tema altında toplanmış, görüşler olumlu ve olumsuz olarak ayrılmıştır. Çalışmanın bulguları Tablo 1'de verilmektedir.

Tablo 1.SPA Otellerine Ait İçerik Analizi

\begin{tabular}{|c|c|c|c|c|}
\hline & Görüşler & Alt Temalar & $\mathrm{n}$ & $\%$ \\
\hline \multirow{4}{*}{$\begin{array}{l}\text { Odaların } \\
\text { Fiziksel } \\
\text { Özellikleri }\end{array}$} & \multirow{3}{*}{ Olumlu } & Odaların güzel ve konforlu olması & 23 & 1.28 \\
\hline & & Odaların geniş-ferah olması & 21 & 1.17 \\
\hline & & Odaların güzel dizayn edilmiş olması & 12 & 0.67 \\
\hline & Olumsuz & $\begin{array}{l}\text { Odalarda eşyaların bozuk-yetersiz } \\
\text { olması }\end{array}$ & 7 & 0.39 \\
\hline \multirow{7}{*}{$\begin{array}{l}\text { Otelin } \\
\text { İmkanları }\end{array}$} & \multirow{5}{*}{ Olumlu } & $\begin{array}{l}\text { COVID-19 pandemisi önlemlerinin } \\
\text { başarılı olması }\end{array}$ & 109 & 6.07 \\
\hline & & Aktivitelerin güzel ve yeterli olması & 30 & 1.67 \\
\hline & & Yürüyüş parkurunun güzel olması & 18 & 1 \\
\hline & & Mimarinin güzel olması & 10 & 0.56 \\
\hline & & Otelin yeni olması & 20 & 1.11 \\
\hline & \multirow[t]{2}{*}{ Olumsuz } & $\begin{array}{l}\text { COVID-19 pandemisi önlemlerinin } \\
\text { başarısız olması }\end{array}$ & 8 & 0.44 \\
\hline & & Aktivitelerin yetersiz olması & 6 & 0.33 \\
\hline \multirow[t]{2}{*}{ Otelin Konumu } & \multirow[t]{2}{*}{ Olumlu } & İstanbul'a yakın olması & 20 & 1.11 \\
\hline & & Konumun güzel olması & 38 & 2.12 \\
\hline \multirow{7}{*}{$\begin{array}{l}\text { Yiyecek ve } \\
\text { İçecek }\end{array}$} & \multirow{4}{*}{ Olumlu } & Yemeklerin lezzetli olması & 157 & 8.75 \\
\hline & & Yemek çeşidinin fazla olması & 24 & 1.34 \\
\hline & & $\begin{array}{l}\text { Özel gruplara hitap eden yemeklerin } \\
\text { bulunması (gluten intoleransı, vegan, } \\
\text { bebek yemeği) }\end{array}$ & 7 & 0.39 \\
\hline & & Servisin başarılı olması & 37 & 2.06 \\
\hline & \multirow[t]{3}{*}{ Olumsuz } & Yemek çeşitlerinin yetersiz olması & 16 & 0.89 \\
\hline & & Yemek sirası & 7 & 0.39 \\
\hline & & Yemeklerin başarısız olması & 16 & 0.89 \\
\hline \multirow{9}{*}{ SPA } & \multirow{7}{*}{ Olumlu } & SPA hizmetlerinin başarılı olması & 90 & 5.01 \\
\hline & & Masajın başarılı olması & 43 & 2.39 \\
\hline & & Havuzların temiz olması & 17 & 0.95 \\
\hline & & Havuz çeşidinin fazla olması & 11 & 0.61 \\
\hline & & Hamamın başarılı olması & 18 & 1 \\
\hline & & Havuzların güzel olması & 65 & 3.62 \\
\hline & & SPA alanının temiz/güzel olması & 28 & 1.56 \\
\hline & \multirow[t]{2}{*}{ Olumsuz } & SPA alanı/havuzların soğuk olması & 6 & 0.33 \\
\hline & & SPA hizmetlerinin başarısız olması & 5 & 0.28 \\
\hline \multirow{7}{*}{$\begin{array}{l}\text { İnsan } \\
\text { Kaynakları }\end{array}$} & \multirow{7}{*}{ Olumlu } & Güler yüzlü olma & 147 & 8.19 \\
\hline & & İlgili olma & 208 & 11.59 \\
\hline & & Yardımsever olma & 26 & 1.45 \\
\hline & & Personel genel olarak iyi & 31 & 1.73 \\
\hline & & Profesyonel olma & 12 & 0.67 \\
\hline & & Kibar olma & 34 & 1.89 \\
\hline & & Saygilı olma & 9 & 0.50 \\
\hline
\end{tabular}


H. Geranaz - D. Yetgin 13/3 (2021) 2800-2818

\begin{tabular}{|c|c|c|c|c|}
\hline & Olumsuz & İlgisiz olma & 11 & 0.61 \\
\hline & & Sayıca yetersiz olma & 8 & 0.44 \\
\hline \multirow{10}{*}{$\begin{array}{l}\text { Otelin } \\
\text { Özellikleri }\end{array}$} & \multirow{9}{*}{ Olumlu } & Manzaranın güzel olması & 14 & 0.78 \\
\hline & & $\begin{array}{l}\text { Dinlenmek ve stres atmak için uygun } \\
\text { ortama sahip olması }\end{array}$ & 14 & 0.78 \\
\hline & & Dizaynın genel olarak güzel olması & 8 & 0.44 \\
\hline & & Otelin sakin olması & 26 & 1.45 \\
\hline & & Çocuklu aileye uygun olması & 29 & 1.61 \\
\hline & & $\begin{array}{l}\text { Özel günlerde yapılan jestlerin başarılı } \\
\text { olması }\end{array}$ & 30 & 1.67 \\
\hline & & Peyzajin güzel olması & 9 & 0.50 \\
\hline & & Kaliteli hizmet sunması & 32 & 1.78 \\
\hline & & Otel çevresinde doğanın güzel olması & 93 & 5.19 \\
\hline & Olumsuz & Kalabalık ve gürültülü olması & 6 & 0.33 \\
\hline \multirow[t]{3}{*}{ Kat hizmetleri } & \multirow[t]{2}{*}{ Olumlu } & Odaların temiz olması & 45 & 2.51 \\
\hline & & $\begin{array}{l}\text { Otelin genel olarak temiz ve hijyenik } \\
\text { olması }\end{array}$ & 103 & 5.74 \\
\hline & Olumsuz & Odaların kirli olması & 7 & 0.39 \\
\hline \multirow[t]{2}{*}{ Fiyatlar } & \multirow[t]{2}{*}{ Olumsuz } & İçeceklerin ekstra ücrete tabi olması & 18 & 1 \\
\hline & & Fiyatların pahalı olması & 6 & 0.33 \\
\hline
\end{tabular}

Tüm kategoriler için olumlu ve olumsuz kullanıcı yorumları ile ilgili örnekler Tablo 2 ve Tablo 3 'te verilmektedir.

Tablo 2.Olumlu kullanıcı yorumlarına ait örnekler

\begin{tabular}{|c|c|}
\hline $\begin{array}{l}\text { Ana } \\
\text { Kategoriler }\end{array}$ & Yorumlar \\
\hline $\begin{array}{l}\text { Odaların } \\
\text { Fiziksel } \\
\text { Özellikleri }\end{array}$ & $\begin{array}{l}\text { “...Oteli çok beğendik. Odaları oldukça geniş ve güzel dizayn edilmişti...” } \\
\text { “...Otel çok temiz, odalarn içi ferah ve çok rahat...” } \\
\text { “...Odalar ve çevre zevkle döşenmiş Odalar çok hoş dizayn edilmiş. ...”" }\end{array}$ \\
\hline $\begin{array}{c}\text { Otelin } \\
\text { İmkanları }\end{array}$ & $\begin{array}{l}\text { "COVID } 19 \text { tedbirleri mükemmel bir şekilde alınmış termal kameralar her yerde dezenfektanlar } \\
\text { içimiz çok rahattı girişten itibaren." } \\
\text { "Otel yeni bir otel olduğundan mimarisiyle görsel bir şölen sunuyor." } \\
\text { “... fiziki yapısı ve mimarisi olağanüstü, akşam şöminenin önünde oturmak çok zevkli..." } \\
\text { “...Aktivite olarak bol tercihli olması grup tatillerini ve çocuklu gezileri renklendirecektir..." }\end{array}$ \\
\hline Otelin Konumu & $\begin{array}{l}\text { “...Harika bir otel konum olarak. İstanbul'a, Bursa'ya ve Ankara'ya yakın olması doğanın içinde } \\
\text { olması...” } \\
\text { "...Otelin konumu çok güzel, orman içerisinde, Sapanca Gölünü görüyor, İstanbul'a } 1 \text { saat } 45 \mathrm{dk} \\
\text { mesafede..." } \\
\text { “...Doğanın kalbinde yer alan ama şehir hayatına çok yakın bir konumda. Biz İstanbul'dan } 1.5 \\
\text { saate vardık, ulaşım yönünden çok avantajl..." }\end{array}$ \\
\hline $\begin{array}{l}\text { Yiyecek ve } \\
\text { İçecek }\end{array}$ & $\begin{array}{l}\text { “...Yemekler çok güzeldi, meze ve yemek çeşitliliği fazlasıyla yeterli...” } \\
\text { “...Yemekler çok güzeldi, restoranda çalışan arkadaşlar güler yüzlü ve hızlı...” }\end{array}$ \\
\hline
\end{tabular}




\begin{tabular}{|c|c|}
\hline & “...Yemekler gayet güzel çeşitleri yeterli gereksiz yı̆̆ılma yok açık büfede..." \\
\hline SPA & $\begin{array}{l}\text { "...Hamam, sauna, buhar odası, kapalı havuz gibi yerler de oldukça ferahtı. Balayı paketimizin } \\
\text { içinde Bali Masajı vardı ve biz çok memnun kaldık, çok rahatlatıcıydı. Kesinlikle masajlarını } \\
\text { tavsiye ederiz..." } \\
\text { "...Havuzlar tertemizdi. Hamam en sevdiğim yerlerden oldu. İstanbul'da gittiğim birç̧k } \\
\text { hamamdan daha güzeldi. Dışarı bulunan tuzlu havuz harikaydı..." } \\
\text { "...Pandemi döneminde geçirdiğim } 1 \text { haftanın kusursuz geçtiğini söyleyebilirim. Hamam, SPA, } \\
\text { sıcak havuz, masaj faaliyetlerinin hijyenik açıdan da çok iyi olmasindan ötürü bütün emek } \\
\text { harcayan personele ve tüm çalışanlara teşekkür etmek..." }\end{array}$ \\
\hline $\begin{array}{c}\text { İnsan } \\
\text { Kaynakları }\end{array}$ & $\begin{array}{l}\text { “...Personel gerçekten çok güler yüzlü, sizi değerli hissettiriyor...” } \\
\text { “...Personel son derece ilgili, güler yüzlü, iyi eğitim almış...” } \\
\text { “...Çalı̧̧anların misafirperverliği, ilgili ve alakah olmaları son derece memnun ediciydi...” }\end{array}$ \\
\hline $\begin{array}{c}\text { Otelin } \\
\text { Özellikleri }\end{array}$ & $\begin{array}{l}\text { “... Otelin muhteşem bir doğası var. Ormanla iç içe. Yürüyüş yapıp temiz havayı bol bol içinize } \\
\text { çekiyorsunuz. Hamakları, salıncakları gezinti yaparken güzel duraklar olarak karşınıza çıkıor..." } \\
\text { “...Otel doğayla iç içe kuş sesleriyle ve çok güzel peyzajı ile bezenmiş bir mimariye sahip. } \\
\text { Ailelerin gönül rahatlığıyla tercih edebileceği imkanlara sahip...” } \\
\text { "...Doğayla iç içe, hijyen kurallarına özenle dikkat edilen ve çalışanların sizi evinizde hissettirdiği } \\
\text { inamılmaz bir tesis...” }\end{array}$ \\
\hline Kat Hizmetleri & $\begin{array}{l}\text { “...Oda temizliği ve havuzların temizliği gerçekten layıkıyla yerine getirilmişti...” } \\
\text { “...Ailecek gittiğimiz ziyaretimizden çok memnun kaldık. Otel ve odalar çok temizdi...” } \\
\text { “...̈̈zellikle pandemi döneminde, tüm hijyen kurallarına özen gösteriliyordu...”" }\end{array}$ \\
\hline
\end{tabular}

Tablo 3. Olumsuz kullanıcı yorumlarına dair örnekler

\begin{tabular}{|c|c|}
\hline Ana Kategoriler & Yorumlar \\
\hline $\begin{array}{c}\text { Odaların } \\
\text { Fiziksel } \\
\text { Özellikleri }\end{array}$ & $\begin{array}{l}\text { “...Banyo kapısının altından sarkan silikon conta, yatak başındaki biri çalışmayan diğeri kırık } \\
\text { okuma lambaları gibi bazı küçük ama sevimsiz arızaların giderilmemesi housekeeping } \\
\text { sorumluluğunda olmalı...” } \\
\text { “... ancak diş fırçası, ayakkabı cilası gibi odalarda bulunması gereken şeyler yok. Şampuanlar } \\
\text { daha güzel kokulu olabilirler. Kış ayları düşünülerek oda balkonlarına ısıtıcı konulması iyi } \\
\text { olabilir...” } \\
\text { "...Oda içinde eksikler ( bornoz, iğne, kese gibi) var. Eksikler için resepsiyonun aranması gerekli } \\
\text { oluyor. Resepsiyon ile bu eksikler için iletişim kurmak tatsız oluyor...” }\end{array}$ \\
\hline Otelin İmkanları & $\begin{array}{l}\text { “...kalitesine güvenerek, SPA, havuz, restoran ve diğer ortak kullanım alanlarındaki tedbirleri } \\
\text { ögrendikten sonra tereddüt etmeden geldik. Ancak sürece yönelik tedbirler anlamında bizi biraz } \\
\text { hayal kırıklı̆̆ına uğrattı..." } \\
\text { “...Pek aktivite yoktu..." } \\
\text { "...Çok fazla aktivite yok ama amacınız dinlenmek doğada olmaksa memnun kalırsinız..." }\end{array}$ \\
\hline
\end{tabular}




\begin{tabular}{|c|c|}
\hline $\begin{array}{c}\text { Yiyecek ve } \\
\text { İçecek }\end{array}$ & $\begin{array}{l}\text { "...Yemek çeşitleri az ve lezzetsiz. Yemek servis eden her büfede sadece } 1 \text { kişi var. Kimseye } \\
\text { yetişemiyorlar..." } \\
\text { "...Yemek kalitesi, çeşitliliği bakımından çok yetersiz. Bu ücreti ödedikten sonra bir daha gelinir } \\
\text { mi?..." } \\
\text { "...Yemekler az çeşitte ve çok ama çok tuzluydu. Ĕ̆ger lezzet çabası için tuz basmışlarsa başarısız } \\
\text { olduklarını söyleyebilirim..." }\end{array}$ \\
\hline SPA & $\begin{array}{l}\text { “...Çocuk havuzunun bulunduğu ortam son derece soğuktu...” } \\
\text { “...Havuz seçenekleri çok fazla ama çocuklar için biraz su soğuk kaçıyor biraz daha sıcak olması } \\
\text { gerekir kış günleri için...” } \\
\text { “...Ancak SPA yetersiz, eleman az, suyu soğuk;15 dakikada odaya dönmek zorunda kaldım...” }\end{array}$ \\
\hline $\begin{array}{c}\text { İnsan } \\
\text { Kaynakları }\end{array}$ & $\begin{array}{l}\text { “...Ayrıca çalışan sayısının az olması sebebiyle mevcut çalışanların muhtemelen yorgunluktan } \\
\text { ilgisiz ve bıkmış olduğunu gördük. Zorla çalıştıkları çok belliydi. Tüm bu şikayetleri dile } \\
\text { getirebileceğimiz bir muhatap bulamadık ne yazık ki..." } \\
\text { "...Akşam saat 22:00 civarı resepsiyona, housekeepinge, front deske 25dk boyunca ulaşamadık, } \\
\text { sonunda ulaştı̆̆ımızda bütün telefonların çaldı̆̆ını ve yetişemediklerini söylediler...” } \\
\text { "...Yemek servis eden her büfede sadece bir kişi var. Kimseye yetişemiyorlar. Çalışanlar çok } \\
\text { ilgisiz..." }\end{array}$ \\
\hline $\begin{array}{c}\text { Otelin } \\
\text { Özellikleri }\end{array}$ & $\begin{array}{l}\text { “...Hafta sonu eski günlerdeki gibi yine kalabalık. Personel sayısında biraz azalma var } \\
\text { arttırılmalı...” } \\
\text { “...Öncelikle otelin konumu güzel orman içinde sessiz sakin fakat konakladı̆̆ımız dönem hafta } \\
\text { sonu olduğu için inanılmaz kalabalık ve gürültülü bir otel oldu...” } \\
\text { “...Bizim gittiğimiz dönemde küçük çocuk nüfusu da çok fazlaydı. Restoranda gürültü ve uğultu } \\
\text { çok fazla idi...” }\end{array}$ \\
\hline Kat Hizmetleri & $\begin{array}{l}\text { “...Banyo çok temizken odanın kirliliği bizi şaşırttı ...” } \\
\text { “...Oda temizliği yetersizdi her yer tozdu...” } \\
\text { “...Yeterli çöp kutusu olmadı̆̆̆ ve tabanın, masaların üzeri toz içindeydi. Tatilimizin ikinci } \\
\text { gününde oda temizlenmesine rağmen tozlar duruyordu...” }\end{array}$ \\
\hline Fiyatlar & $\begin{array}{l}\text { “...Böyle bir otelde tek beğenmediğimiz yarım pansiyon olup çay kahve ekstra ücretli olması...” } \\
\text { “...Tek şikâyetimiz restoranda yalnızca bir adet soft içecek ücretsiz olarak veriliyor onun dışında } \\
\text { içecekler ekstra ücrete tabi olmasıydı...” } \\
\text { “...Ekstra ücret ödediğimiz içeceklerin fiyatı abartı derecede pahalıydı...” }\end{array}$ \\
\hline
\end{tabular}

\section{Odaların Fiziksel Özellikleri}

Odaların fiziksel özellikleri ana teması ile ilgili 63 adet yorum bulunmaktadır ve olumlu yorumlar sayıca daha fazladır. Çalışmada sırasıyla odaların güzel ve konforlu olması (\%1.28), odaların geniş-ferah olması (\%1.17), odaların güzel dizayn edilmiş olması (\% 0.67) olumlu alt temaları ile odalarda eşyaların bozuk-yetersiz olması (\%0.37) olumsuz alt teması yer almaktadir.

Konukların odaların fiziksel özellikleri ile ilgili memnun kaldıkları durumlar aşağıda belirtilmiştir:

- Odaların geniş ve ferah olması

- Odaların konforlu olması ve odalarda bulunması gereken eşyaların eksiksiz olması

- Odaların dizaynının güzel ve şık olması

- Odaların ve odadaki eşyaların yeni olması 


\section{H. Geranaz - D. Yetgin 13/3 (2021) 2800-2818}

- Odaların manzarasının güzel olması

Konukların odaların fiziksel özellikleri ile ilgili memnun kalmadıkları durumlar aşağıda belirtilmiştir:

- Odalarda sigara kokusunun olmasi

- Odaların iyi isınmaması

- Odalarda eksik eşya bulunması

- Odalarda teknik sorunlar yaşanması

\section{Otelin İmkanları}

Otelin imkanları ana teması ile ilgili 201 yorum bulunmaktadır ve olumlu yorumların daha fazla olduğu görülmektedir. "Otelin imkanları" ana temasında sırasıyla COVID-19 pandemisi önlemlerinin başarılı olması (\%6.07), aktivitelerin güzel ve yeterli olması (1.67), otelin yeni olması (\%1.11), yürüyüş parkurunun güzel olması (\%1), mimarinin güzel olması (\%0.56) olumlu alt temaları ile COVID-19 önlemlerinin başarısız olması (\%0.44) ve aktivitelerin yetersiz olması (\%0.33) olumsuz alt temaları yer almaktadır.

Konukların otelin imkanları ile ilgili memnun kaldıkları durumlar aşağıda belirtilmiştir:

- COVID-19 pandemisi tedbirlerine dikkat edilmesi ve gerekli önlemlerin alınması

- Yürüyüş parkurunun bakıml, uzun ve keyifli olması

- Otelin yeni yapılmış olması

- Otelin mimarisinin güzel olması ve çevresindeki doğayla uyumlu olması

- Otelde herkese hitap edecek çeşitlilikte farklı aktivitelere yer verilmesi

- Lobinin ferah, geniş ve şık dizayn edilmiş olması

Konukların otelin imkanları ile ilgili memnun kalmadıkları durumlar aşağıda belirtilmiştir:

- Otelde COVID-19 pandemisi tedbirlerinin eksik olması, sosyal mesafe ve hijyene yeterince dikkat edilmemesi

- COVID-19 pandemisi nedeniyle zaman zaman etkinliklere ara verilmesi ile etkinlik çeşidinin azalması

\section{Otelin Konumu}

Otelin konumu ana teması ile ilgili toplam 58 yorum bulunmakta olup yorumların tümü olumludur. Otelin konumu temasında sırasıyla konumun güzel olması (\%2.12) ve İstanbul'a yakın olması (\%1.11) alt temaları yer almaktadır.

Konukların otelin konumu ile ilgili memnun kaldıkları durumlar aşağıda belirtilmiştir:

- İstanbul'a yakın olmasıyla kısa süreli tatiller için bile ulaşılabilir olması

- Otellerin Sapanca Gölü'ne yakın olması nedeniyle güzel bir manzaraya sahip olması

- Otellerin orman içinde sessiz, sakin ve huzurlu bir alana sahip olacak şekilde konumlandırılması

Yiyecek ve İçecek

Yiyecek ve içecek ana teması ile ilgili 264 yorum bulunmaktadır ve olumlu yorumlarının daha fazla olduğu görülmektedir. Yiyecek ve içecek ana temasında sırasıyla yemeklerin lezzetli olması (\%8.75), servisin başarılı olması (\%2.06), yemek çeşidinin fazla olması (\%1.34), özel gruplara hitap eden yemeklerin bulunması (\%0.39) olumlu alt temaları ile yemek çeşitlerinin yetersiz olması (\%0.89), yemeklerin başarısız olması (\%0.89) ve yemek sırası (\%0.39) olumsuz alt temaları yer almaktadır.

Konukların yiyecek ve içecek ile ilgili memnun kaldıkları durumlar aşağıda belirtilmiştir:

- Yemeklerin lezzetli olması

- Yemek çeşitliliğinin fazla olması

- Farklı beslenme rejimlerine uygun yemeklerin şefler tarafından özenle hazırlanması

- Yemek servisinin hizlı olması

- Açık büfede sıra oluşmaması

- Yemek servisi yapan personelin ilgili, güler yüzlü ve yardımsever davranışları

- Yemek yenilen ortamın ferah olması, güzel müziklerin eşlik etmesi

Konukların yiyecek ve içecek ile ilgili memnun kalmadıkları durumlar aşağıda belirtilmiştir: 


\section{H. Geranaz - D. Yetgin 13/3 (2021) 2800-2818}

- Açık büfede yemek çeşidinin yetersiz olması

- Yemeklerin lezzetsiz olmasi

- Yemeklerin porsiyonlarının fiyatına göre küçük olması

- Açık büfede uzun yemek sıraları oluşması

- Servis personelinin ilgisiz olması ve servisin yavaş olması

- Yemeklerin soğuk olması

\section{SPA}

SPA teması ile ilgili toplam 283 yorum bulunmaktadır ve olumlu yorumların sayıca daha fazla olduğu görülmektedir. SPA ana temasında sırasıyla SPA hizmetlerinin başarılı olması (\%5.01), havuzların güzel olması (\%3.62), masajın başarılı olması (\%2.39), SPA alanının temiz/güzel olması (\%1.56), hamamın başarılı olması (\%1), havuzların temiz olması (\%0.95), havuz çeşidinin fazla olması (\%0.61) olumlu alt temaları ile SPA alanı/havuzların soğuk olması (\%0.33) ve SPA hizmetlerinin başarısız olması $(\% 0.28)$ olumsuz alt temaları yer almaktadır.

Konukların SPA ile ilgili memnun kaldıkları durumlar aşağıda belirtilmiştir:

- $\quad$ SPA alanının geniş ve ferah olması

- SPA alanın huzur verici bir atmosfer yaratacak şekilde güzel dizayn edilmiş olması

- SPA alanının, havuzların ve hamamın hijyenik olması ve belirli aralıklarla düzenli olarak temizlenmesi

- Herkese hitap edebilecek çeşitlilikte pek çok havuz bulunması

- Çocuklara uygun çok sayıda havuz bulunması

- Havuzların büyük olması

- Hamam alaninin ve hizmetlerinin güzel olmasi

- SPA hizmetlerinin başarılı olması ve zamanında yürütülmesi

- Masajin başarılı olması

- SPA'da çalışan personelin profesyonel olması

- SPA'da çalışan personelin konuklara detaylı bilgilendirmeler vererek SPA'da oldukları süre boyunca ilgili davranmaları

Konukların SPA ile ilgili memnun kalmadıkları durumlar aşağıda belirtilmiştir:

- Havuzların çocuklar için soğuk olması

- Islak alanlar arası geçişin yapıldığı yerlerin soğuk olması

- SPA alanının yeterince hijyenik olmaması

- SPA hizmetlerinin başarısız olması, masaj randevularına geç başlanması

- Masajın profesyonel olmayan kişilerce yapılması ve başarısız olması

\section{İnsan Kaynakları}

İnsan kaynakları ana teması 486 yorumla en çok yorum alan ana tema olmuştur. Bu kategoride de olumlu yorumlar sayıca olumsuz yorumlara göre çok daha fazladır. İnsan kaynakları kategorisinde sırasıyla ilgili olma (\%11.59), güler yüzlü olma (\%8.19), kibar olma (\%1.89), genel olarak iyi (\%1.73), yardımsever olma (\%1.45), profesyonel olma (0.67), saygılı olma (\%0.50) olumlu alt temaları ile ilgisiz olma $(\% 0.61)$ ve sayıca yetersiz (0.44) olma alt temaları bulunmaktadır.

Konukların insan kaynakları ile ilgili memnun kaldıkları durumlar aşağıda belirtilmiştir:

- Personelin ilgili olması ve konuklara her konuda yardımcı olmaya çalışması

- Personelin sıcak bir karşılama yapması

- Personelin samimi ve güler yüzlü olarak konuklara kendini evinde hissettirmesi

- Personelin yapıcı olması ve sorunları hızlı bir şekilde çözerek telafi etmesi

- Personelin eğitimli ve profesyonel olmasi

- Personelin kibar ve saygılı davranışlar göstermesi

Konukların insan kaynakları ile ilgili memnun kalmadıkları durumlar aşağıda belirtilmiştir:

- Personelin konukların istekleri ve sorunları karşısında ilgisiz bir tavır sergilemesi

- Personelin konuklara kaba ve saygisız davranması 


\section{H. Geranaz - D. Yetgin 13/3 (2021) 2800-2818}

- Otelde sayıca az personel bulunması nedeniyle hizmetlerin aksaması

- Personelin güler yüzlü olmaması, soğuk bir tavır sergilemesi

\section{Otelin Özellikleri}

Otelin özelliklerine dair toplam 261 adet yorum bulunmaktadır ve yorumların çoğunluğunun olumlu olduğu görülmektedir. Otelin özellikleri ana temasında sırasıyla otel çevresinde doğanın güzel olması (\%5.19), kaliteli hizmet sunması (\%1.78), özel günlerde yapılan jestlerin başarılı olması (\%1.67), çocuklu aileye uygun olması (\%1.61), otelin sakin olması (\%1.45) , manzaranın güzel olması (\%0.78), dinlenmek ve stres atmak için uygun ortama sahip olması (\%0.78), peyzajın güzel olması (\%0.50), dizaynın genel olarak güzel olması (\%0.44) olumlu alt temaları ile kalabalık ve gürültülü olması (\%0.33) olumsuz alt teması yer almaktadır.

Konukların otelin özellikleri ile ilgili memnun kaldıkları durumlar aşağıda belirtilmiştir:

- Otel çevresinde doğanın güzel olması, bol yeşillik ve temiz hava

- Otel çevresinin kuş sesleri ve göl manzarasıyla huzurlu olması ve stres atmak için uygun olması

- Sakin ve sessiz atmosferiyle dinlendirici olmasi

- Doğum günü, yıl dönümü, balayı gibi özel günlerde otel personeli tarafından jestler yapılması ve bu gibi organizasyonları gerçekleştirmek isteyen konuklara gerekli yardımların yapılması

- Otel bahçesinde peyzajın güzel olması, dışarıda yeterli oturma alanının bulunması

- Çocuklar için havuzlar ve etkinlikler yönünden zengin bir konsept sunmasıyla çocuklu aileler için uygun olmasi

- Odalarda ve açık alanlarda güzel bir manzaranın olması

- Otelin genel olarak zevkli bir dekorasyonunun olması

- Otelin her yönüyle kaliteli hizmet sunması

Konukların otelin özellikleri ile ilgili memnun kalmadıkları durumlar aşağıda belirtilmiştir:

- Otelin özellikle hafta sonları ya da resmî tatillerde kalabalık olması

- Çocukların çok olduğu dönemlerde otelin gürültülü olması

\section{Kat Hizmetleri}

Kat hizmetleri ana kategorisi ile ilgili toplam 155 adet yorum bulunmaktadır ve olumlu yorumlar sayıca daha fazladır. Kat hizmetleri temasında sırasıyla otelin genel olarak temiz ve hijyenik olması (\%5.74), odaların temiz olması (\%2.51) olumlu alt temaları ile odaların kirli olması (\%0.39) olumsuz alt teması yer almaktadır.

Konukların kat hizmetleri ile ilgili memnun kaldıkları durumlar aşağıda belirtilmiştir:

- Otelin genel kullanım alanlarının ve bütünün hijyen kurallarına uygun ve temiz olması

- Odaların ve banyoların temiz olması

- Ortak tuvaletlerde gerekli hijyen kurallarına uyulması, COVID-19 pandemisi tedbirleri kapsamında dezenfektan bulundurulması

Konukların kat hizmetleri ile ilgili şikâyet ettikleri konular aşağıdaki gibidir:

- Odaların yeterli temizlik yapılmadan konuklara sunulması

- Odalarda eşyaların ve yerlerin tozlu olması

- Oda tuvaletlerinin yeterince temiz olmamasi

- Ortak alanların tozlu olması

Fiyatlar

Fiyatlar ana temasında toplam 24 adet yorum bulunmaktadır. Fiyatlara dair olumlu yorum sayısı çok az olduğundan bulgulara dahil edilmemiştir, sadece olumsuz yorumlar incelenmiştir. Fiyatlar temasında sırasıyla içeceklerin ekstra ücrete tabi ve pahalı olması (\%1) ve fiyatların pahalı olması (\%0.33) olumsuz alt temalarına yer verilmiştir.

Konukların fiyatlar ile ilgili şikayetçi oldukları durumlar aşağıda belirtilmiştir:

- Restoranda bir içecekten sonrasının ücretli olması ve içecek fiyatlarının yüksek olması

- Fiyat-performans oranının başarısız olması 


\section{H. Geranaz - D. Yetgin 13/3 (2021) 2800-2818}

- Otelin genel olarak fiyatının çok yüksek olması

\section{TARTIȘMA}

Çalışma sonuçları yorumların sırasıyla insan kaynakları, SPA, yiyecek ve içecek kategorisinde yoğunlaştığını göstermektedir. Yorumların geneline bakıldığında olumsuz yorumların az sayıda olduğu görülmektedir. Araştırma kapsamında 5 yıldızlı oteller seçildiği için belirli bir hizmet kalitesinin sağlanması nedeniyle olumsuz yorumların sayıca az olduğu söylenebilir.

En çok yorum alan ana tema insan kaynaklarıdır. Olumlu alt temalar ise sırasıyla ilgili olma, güler yüzlü olma ve kibar olma olarak bulunmuştur. Literatür incelendiğinde bu konuyla ilgili benzer çalışmalarda da aynı sonuca ulaşıldığı görülmektedir. Çoban vd. (2019) Eskişehir şehir otellerinin e-yorumlarını inceledikleri çalışmalarında insan kaynakları kategorisinin en çok yorum alan kategori olduğu sonucuna ulaşmıştır. Gürbüz ve Ormankıran (2020) 5 yıldızlı Belek otellerinin yorumlarını incelemiş, personel davranışının en çok yorum alan kategori olduğunu saptamıştır. Doğançili vd. (2018) Göller Bölgesi otellerinin Tripadvisor yorumlarını incelemiş, en çok yorum alan olumlu unsurun personel olduğu sonucuna ulaşmıştır.

İnsan kaynaklarından sonra en çok yorum alan kategori SPA olmuştur. SPA kategorisinde ise en çok yorum alan alt tema "SPA hizmetlerinin başarılı olması" olumlu temasıdır. Bunu havuzların güzel olması, masajın güzel olması, hamamın başarılı olması, SPA alanının temiz/güzel olması, havuzların temiz olması ve havuz çeşitliliğin fazla olması alt temaları izlemektedir. Bertan vd. (2015) Türkiye'de termal otellere dair Tripadvisor yorumlarını incelemiştir. Yorumlarda en sık kullanılan ikinci kelimenin "havuz" olduğunu ve termal otellerde havuzun konukların ilgisini çeken konuların başında geldiğini belirtmiştir. Araştırmamızda havuzlarla ilgili üç alt tema altında çok sayıda yorum bulunması bunu destekler niteliktedir. Küçükusta ve Giuliett (2019) temizlik ve durum, ortam, SPA personelinin görünümü ve terapistlerin kişiselleştirilmiş hizmet anlayışının müşterilerin SPA hizmeti deneyimini etkileyen önemli SPA özellikleri olduğunu saptamıştır. Bu çalışma, araştırmamızda SPA kategorisinde 3.sırada yer alan SPA alanının temiz/güzel olması sonucunu destekler niteliktedir.

Araştırma kapsamında en çok yorum alan üçüncü kategori ise yiyecek ve içecektir. Bu kategori altında en çok yorum "yemeklerin lezzetli olması" alt temasına gelmiştir. An (2018) Yeni Zelanda'da lüks oteller üzerinde yaptığı araştırmada yiyecek ve içeceğin en çok yorum alan kategoriler arasında olduğu sonucuna ulaşmıştır. Benzer şekilde Doğançili vd. (2018) ve Çoban vd. (2019) tarafından yapılan çalışmalarda yiyecek ve içecek hizmetleri en çok yorum alan ilk üç kategori arasında yer almaktadır. Şahin vd. (2020) Kuşadası'nda yaptıkları araştırmada yorumların büyük kısmının personel ve yiyecekler üzerinde yoğunlaştığını bulmuştur.

Araştırmanın bulgularına göre yiyecek-içecek kategorisinde olumlu yorumlar fazla olsa da bu hizmetlerden memnun olmayan bir kesimin de bulunduğu görülmektedir. Yemek çeşidinin az olması ve yemeklerin başarısız olması belirtilen yorumlar arasındadır. Olumlu yorumların çokluğu göz önüne alındığında yiyecekiçecek hizmetleri ile ilgili problemlerin az ve dönemsel olduğu söylenebilir.

Otelin özellikleri ana temasındaki yorumlar incelendiğinde konukların SPA otellerinde sessizlik, sakinlik, huzurlu atmosfer ve doğanın güzel olması konularına önem verdikleri görülmektedir. Bu durum SPA otellerini tercih eden kişilerin motivasyonları ile yakından ilgilidir. Küçükusta vd. (2013) konukların otellerdeki SPA merkezlerini ziyaret etme motivasyonlarının sırasıyla rahatlama (gevşeme), kendini şımartma ve güzellik olduğunu saptamıştır. Araştırmamızda konuklar otelin çevresindeki doğanın güzelliğinden ve sakinliğinden etkilendiklerini, bu otellerin huzur verici, stres atmaya uygun ve dinlendirici bir atmosfere sahip olduklarını belirtmişlerdir ve otelin imkanları alt temasında "otel çevresinde doğanın güzel olması" en çok yorum alan kategori olmuştur.

Kat hizmetleri kategorisinde, konukların otellerin genel olarak temiz ve hijyenik olması ve odaların temiz olmasına önem verdikleri görülmektedir. Sezen Doğancili vd. (2018) ve Barreda ve Bilgihan'ın (2013) çalışmalarında da temizliğin çevrim içi yorumlarda öne çıkması bu araştırmayı destekler niteliktedir. Odaların fiziksel özellikleri ile ilgili yorumlar incelendiğinde, konukların odaların yeni olmasından, büyük ve ferah olmasından ve güzel dizayn edilmesinden memnun oldukları görülmektedir. Limberger vd. (2014) Brezilya' daki otellerin Tripadvisor yorumlarını incelemiş, oda, hizmet ve değer (maliyet-fayda) kriterleri ile genel memnuniyet arasında yüksek bir korelasyon bulunduğunu saptamıştır. Li vd. (2013) tarafından 


\section{H. Geranaz - D. Yetgin 13/3 (2021) 2800-2818}

gerçekleştirilen araştırma da konukların oda büyüklüğü ve dekorasyonuna önem verdiğini doğrular niteliktedir.

Otelin imkanları kategorisinde COVID-19 pandemisi koşullarının etkisiyle pandemi önlemlerinin başarılı olması alt temasındaki yorumların sayıca fazla olduğu görülmektedir. Aktivitelerin yeterli olması ve otelin yeni olması konukları memnun eden diğer faktörler arasındadır. Pandemi sürecinde otelin odaları, genel alanları, yiyecek-içecek ve SPA alanları gibi tüm bölümlerinde gerekli hijyen kurallarına uyulması, belirli aralıklarla dezenfeksiyon işlemlerinin yapılması ve sosyal mesafe hususunda titiz davranılması konuk memnuniyeti açısından büyük önem taşımaktadır.

Otelin konumu ile ilgili hiçbir olumsuz yoruma rastlanmamıştır. Sapanca'daki SPA otelleri başta İstanbul olmak üzere büyük şehirlere yakın olmasıyla konum konusunda avantajlıdır. Bayram vd. (2014) tarafından yapılan çalışmada da konumun yorumlarda ön plana çıktığ yorumlardan oluşmasıyla dikkat çekmektedir. Otellerin yarım pansiyon uygulamaları nedeniyle içeceklerden ekstra ücret alması konuklar tarafından eleştirilen önemli noktalardan biri olmuştur.

SPA otelleri dinlenmek, rahatlamak, stres atmak gibi motivasyonlara sahip turistler tarafından tercih edildiğinden şehir otellerinden farklı özelliklere sahiptir. Bu otelleri tercih eden kişiler tüm günü otel içinde ve otelin imkanlarından özellikle de SPA hizmetlerinden yararlanarak geçirmektedir. Tüm bu etkenler göz önüne alındığında, dinlenmek ve rahatlamak için uygun bir atmosferin sağlanması, SPA hizmetlerinin başarılı yürütülmesi, yiyecek-içecek hizmetleri, personelin tutumu, yeterli sayıda aktivite seçeneğinin bulunması SPA otelleri için önem taşımaktadır. Çalışmanın sonuçları dikkate alındığında SPA otellerini tercih eden turistlerin en çok insan kaynaklarına, SPA'ya, yiyecek ve içecek hizmetlerine, otelin özelliklerine ve otelin imkanlarına önem verdikleri görülmektedir.

\section{SONUÇ}

Çalışmanın amacı, Sapanca'da SPA otellerini ziyaret eden turistlerin bu otellere yönelik beklentilerini ortaya koymaktır. Bu doğrultuda çevrim içi yorumlar incelenerek konukların memnuniyetini etkileyen başlıca faktörler belirlenmiştir. Çalışmanın sonuçları değerlendirildiğinde SPA otellerinde konukların insan kaynakları, SPA, yiyecek ve içeceğe en çok önem verdikleri görülmektedir. İnsan kaynaklarına yapılan yorumların diğer kategorilere yapılan yorumlardan fazla olması konaklama işletmelerinde konukların memnuniyetinde insan kaynaklarının ne denli önemli olduğunu vurgulamaktadır. Turizm emek yoğun bir sektördür ve personel konuklarla birebir iletişim halindedir. Bu nedenle personelin tavır ve tutumları konukların memnuniyeti üzerinde önemli bir etkiye sahiptir.

SPA kategorisinde olumlu yorumlarda SPA hizmetlerinin başarılı olması, masajın başarılı olması, havuzların temiz olması yer alırken olumsuz yorumlarda SPA alanı/havuzların soğuk olması ve SPA hizmetlerinin başarısız olması ön plana çıkmıştır. Olumsuz yorumlar sayıca çok azdır. Bu durum Sapanca'daki 5 yıldızlı SPA otellerinin SPA hizmetleri konusunda başarılı olduğunun göstergesidir. Olumsuz yorumlardan yola çıarak, SPA bölümünde farklı alanlar arasında konukların üşümemesi için gerekli ısıtmanın yapılması önem taşımaktadır.

Yiyecek ve içecek ana temasında hem olumlu hem de olumsuz yorumlarda yemeklerin lezzeti ve yemek çeşitliliği ön plana çımaktadır. SPA otelleri yemeklerin lezzetine önem vermeli ve herkese hitap edecek şekilde bir yemek çeşitliliği sağlamalıdır. Bunun yanı sıra özellikle tatil dönemlerindeki yorumlarda açık büfe sıraları ve personelin sayıca yetersiz kalması konularında şikâyet olduğu görülmektedir. Doluluğun yüksek olduğu tatil günlerinde sıra olmasını önlemek ve servisi hızlandırmak için yiyecek-içecek bölümünde konuklara yardımcı olacak daha çok personelin bulundurulmasına önem verilmelidir.

Otelin özellikleri ana teması kapsamında konukların otel çevresindeki doğaya, kaliteli hizmet sunulmasına ve özel günlerde yapılan jestlere önem verdikleri görülmektedir. Turizm sektöründe rekabetin giderek arttığ1 günümüzde konuklara kişiselleştirilmiş hizmetler sunulması ön plana çıkmaktadır. Kişiselleştirilmiş hizmetler işletmenin rekabet gücünü artırmakta, konuk memnuniyeti ve sadakatini sağlamaktadır (Zhang, 2018:111). "Özel günlerde yapılan jestlerin başarılı olması" alt temasındaki yorumlar bu bağlamda değerlendirilebilir. Bu yorumlarda kişiler doğum günü, yıl dönümü, balayı gibi özel günlerde otel personelinin hazırladıkları jestler ve sürprizlerden duydukları memnuniyeti belirterek personele teşekkürlerini iletmiştir. Ayrıca gluten hassasiyeti olan, vegan ya da vejetaryen olan kişilere ve bebeklere özel 


\section{H. Geranaz - D. Yetgin 13/3 (2021) 2800-2818}

yemeklerin şefler tarafından özenle hazırlanması da müşterilerin üzerinde durduğu konular arasında yer almıştır. SPA otelleri ve diğer konaklama işletmeleri bu durumun üzerinde durmalı, konukların kendilerini özel hissetmeleri için gerekenleri mutlaka yapmalıdır.

Kat hizmetleri bağlamında otelin genel olarak temiz ve hijyenik olmasının memnuniyeti etkileyen faktörler arasında yer aldığı görülmektedir. Otelin temizliği ile ilgili çok sayıda ve detaylı yorumlar yer almaktadır. Bu durum konukların pandemi nedeniyle hijyen ve temizlik uygulamaları konusunda ekstra hassasiyet göstermesinin bir sonucudur. Otelin genel kullanım alanlarının ve odalarının hassasiyetle temizlenmesi konuk memnuniyeti açısından önem taşımaktadır. Odalarla ilgili yorumlarda konuklar odaların geniş, ferah, yeni ve güzel dizayn edilmiş olmasından memnuniyet duyduklarını belirtmiştir. SPA otellerinde şehir otellerine kıyasla konuklar otelde daha fazla vakit geçirdiğinden odaların büyüklüğü ve ferahlığı daha önemli bir durum olarak karşımıza çıkmaktadır. Ayrıca SPA otellerinde konuklar dinlenme ve huzur motivasyonunu taşıdıklarından dekorasyonda kullanılan ögeler, renkler ve detayların bu amaca yönelik seçilmesi gerekmektedir.

Turizmde konaklama tesisi ya da destinasyon seçiminde mesafe önemli faktörlerin başında gelmektedir. Araştırmamızda da konuklar İstanbul'a yakın olması nedeniyle Sapanca otellerini tercih ettiklerini belirtmiştir. Araştırma kapsamında olumsuz yorumlarda fiyat kategorisi öne çıkmaktadır. Bazı otellerde yarım pansiyon uygulamasının olduğu ve konukların içecekler için sürekli ücret ödemek durumunda kalmaktan rahatsızlık duydukları görülmektedir. Bu şikayetlerin göz önüne alınarak içeceklerin de dahil olduğu alternatif paketlerin önerilmesi faydalı olacaktır.

\section{Sinırlılıklar ve Öneriler}

Bu çalışmada sadece 5 yıldızlı oteller ele alınmıştır. Diğer yıldız kategorilerinde yer alan konaklama tesislerinin gelecek araştırmalara dahil edilmesi özellikle SPA hizmetlerinin analiz konusunda daha geniş bir bakış açısı kazandırabilir. Çalışma kapsamında sadece Türkçe yorumlar incelenmiştir. Gelecekteki çalışmalarda diğer dillerdeki yorumların incelenmesi yabancı turistlerin beklentilerini, memnun oldukları ve olmadıkları noktaları anlamak açısından faydalı olacaktır.

Araştırma kapsamında 1 Nisan 2020-1 Nisan 2021 tarih aralığındaki bir yıllık yorumlar incelenmiştir. Gelecek çalışmalarda daha geniş bir tarih aralığı seçilebilir. Ayrıca Türkiye'de farklı bölgelerde yer alan SPA otellerinde araştırmalar yapılarak sonuçlar karşılaştırılabilir ve Türkiye'deki SPA otelleri hakkında daha bütüncül bir tablo ortaya çıkarılabilir.

Araştırmada Tripadvisor.com yorumları incelenerek konukların SPA otelleri ile ilgili memnun oldukları ve olmadıkları durumlar hakkında genel bir çerçeve çizilmiştir. İnsan kaynakları hakkındaki yorumların sayıca fazlalığı insan kaynaklarının önemini vurgulamaktadır. SPA otellerinde personelin en iyi şekilde çalışabilmesi için eğitimlerine ve motivasyonlarını sağlamaya önem verilmelidir. Personelin eğitilmesi ve yüksek standartlarda hizmet vermelerinin sağlanması otel işletmelerinde konuk memnuniyetini artırıcı etkiye sahiptir (An, 2018). Personelin motivasyonun sağlanması için terfi edebilme ve ödüllendirme sistemleri etkin bir şekilde kullanılmalıdır (Gökkaya ve Türker, 2018:25).

SPA otellerinde SPA hizmetlerinin başarısı genel memnuniyet üzerinde önemli bir etkiye sahiptir. SPA ile ilgili yorumlarda havuz çeşitliliği üzerinde durulduğu görülmektedir. Herkese hitap edebilmesi ve aynı zamanda kalabalık oluşmasını önlemesi açısından havuzların çeşitlendirilmesi önemlidir. İşletmelerin bu konu üzerinde durması ve yatırım yapması memnuniyet açısından önem arz etmektedir. Bunun yanında SPA hizmetlerinin eksiksiz yürütülmesi için gerekli planlamalar yapılmalı, temizliğe önem verilmelidir. SPA içinde ve SPA'ya geçiş alanlarında konukların üşümemesi için uygun sıcaklık sağlanmalıdır. Konuklar yorumlarında SPA'da personelin ilgisinin ve bilgilendirmesinin önemli olduğunu belirtmiştir. Bu bağlamda konuklara SPA'daki tüm olanaklar hakkında bilgi verip onlara yardımcı olacak yeterli personel bulunması önem taşımaktadır. SPA'daki ana hizmetlerden biri masaj olduğundan alanında profesyonel ve deneyimli terapistlerin istihdam edilmesi önem taşımaktadır.

Yemekler hakkında yorumların çoğu olumlu olsa da az sayıda konuk yiyeceklerin lezzetinden memnun olmadıklarını ve çeşidin az olduğunu belirtmiştir. Belirli bir standartın sürdürülmesi için her zaman yiyecekiçecek çeşitliliğini korumak önem taşımaktadır. Konuklar SPA otellerini sağlık ve welness amaçlı ziyaret ettiklerinden yiyecek ve içecek sunumunun kalitesi büyük önem taşımaktadır. Sağlıklı ve ilgi çekici menülerin 


\section{H. Geranaz - D. Yetgin 13/3 (2021) 2800-2818}

hazırlanması, menülerde besin değerleri ve kalorilere yer verilmesi gerekmektedir (Giritlioğlu vd., 2014). Çevrimiçi tüketici yorumlarının konaklama işletmeleri tarafından dikkatle incelenmesi, konukların istek ve şikayetlerinin eş zamanlı olarak takip etmesi ve en kısa zamanda dönüş yapması konuk memnuniyeti açısından işletmeye değer katacaktır (Yetgin vd., 2018; Çoban vd., 2019:554; Yetgin vd., 2020: 2102; Battal vd., 2019). Konukların yorumlarında dinlenme ve stres atmalarına yardımcı olan sakin, doğal güzelliklerle çevrili otellerden memnun kaldıkları görülmektedir. SPA otellerinin çevresindeki doğa ile uyumlu bir mimariye sahip olması ve bu uyumu otel içinde de sürdürmesi gerekmektedir. Ayrıca konuklar doğayla iç içe olmak istediklerinden SPA otelleri yürüyüş parkurlarına ve peyzaja önem verilmelidir. Olumsuz yorumlarda aktivitelerin az olmasından şikâyet eden konukların olduğu görülmektedir. Aktivite sayısının ve dış mekânda zaman geçirilecek alanların artırılması faydalı olacaktır.

\section{KAYNAKÇA}

An, T. (2018). Guest Satisfaction in New Zealand Luxury Hotels: a Study of Reviews from TripAdvisor. (Yayımlanmamış Yüksek Lisans Tezi). Auckland University of Technology, Auckland.

Barca, M., Akdeve, E. ve Balay, İ.G.(2013).Türkiye Sağlık Turizm Sektörünün Analizi ve Strateji Önerileri, İşletme Araştırmaları Dergisi, 5(3), 64-92.

Barreda, A. ve Bilgihan, A.(2013). An analysis of user-generated content for hotel experiences. Journal of Hospitality and Tourism Technology, 4(3), 263-280.

Başkale, H. (2016). Nitel Araştırmalarda Geçerlik, Güvenirlik ve Örneklem Büyüklüğünün Belirlenmesi. Dokuz Eylül Üniversitesi Hemşirelik Fakültesi Elektronik Dergisi, 9(1), 23-28.

Battal, S., Kayalı, E., Ural, Ü. S. ve Yetgin, D. (2019). A Survey on e-complaints: The case of Turkish Airlines. Journal of Tourism Leisure and Hospitality, 1(1), 15-21.

Bayram, M., Bertan, S. ve Ertaş, M.(2014). Sosyal Medya Kullanıcılarının Konaklama Tesislerine Yönelik Algılamaları: Pamukkale ve Karahayıt Örneği. Uluslararası Hakemli Beşeri ve Akademik Bilimler Dergisi, Kış Dönemi, 3(10), 139-150.

Bayram, M.(2018).Otel Konuk Memnuniyetini Etkileyen Unsurlar. Seyahat ve Otel İşletmeciliği Dergisi, 15(2), 352-369.

Berezina, K., Bilgihan, A., Cobanoglu, C. ve Okumus,F.(2016).Understanding Satisfied and Dissatisfied Hotel Customers: Text Mining of Online Hotel Reviews. Journal of Hospitality Marketing \& Management, 25(1), $1-24$.

Bertan, S., Bayram, M. ve Benzergil, N. (2015). The evaluation of thermal hotels' online reviews. Tourism: An International Interdisciplinary Journal, 63 (1), 53-65.

Chan, N.L. ve Guillet, B.D.(2011).Investigation of Social Media Marketing: How Does The Hotel Industry In Hong Kong Perform In Marketing On Social Media Websites?. Journal of Travel \& Tourism Marketing, 28 (4), 345-368.

Cohen, M. (2008).Spas, Wellness and Human Evolution. M.Cohen G.Bodeker (Ed.), Understanding The Global Spa Industry: SPA Management içinde (3-25 ss.). Butterworth-Heinemann:Burlington.

Creswell, J. W. (2013). Nitel Araştırma Yöntemleri. (Çev. M.Bütün ve S.B. Demir). Ankara: Siyasal Kitabevi.

Çelik A. (2009). Sağlık Turizmi Kapsamında Termal İşletmelerde Sağllk Hizmetleri Pazarlaması ve Algılanan Hizmet Kalitesi: Balçova Termal İşletmesinde Bir Uygulama. (Yayımlanmamış Yüksek Lisans Tezi), Dokuz Eylül Üniversitesi Sosyal Bilimler Enstitüsü İşletme Anabilim Dalı Hastane ve Sağlık Kuruluşları Yönetimi Program1, İzmir.

Çoban, S., Çoban, E. ve Yetgin, D. (2019). Şehir Turizminde Faaliyet Gösteren Otellere Yönelik E-Yorumların İncelenmesi: Eskişehir İli Örneği. Türk Turizm Araştırmaları Dergisi, 3(3), 542- 558.

Çuhadar, M., Köseoğlu, S. ve Gültepe, Ö. 2018). Isparta İlindeki Konaklama İşletmelerine Yönelik Çevrimiçi Müşteri Değerlendirmelerinin İncelenmesi: Tripadvisor Örneği. Süleyman Demirel Üniversitesi İktisadi ve İdari Bilimler Fakültesi Dergisi, 23(1), 227-239.

Denizci Guillet, B. ve Küçükusta, D.(2019). Analyzing Attributes of the Spa Service Experience: Perceptions of Spa-Goers Traveling to Hong Kong. Journal of China Tourism Research, 15(1), 66-83. 


\section{H. Geranaz - D. Yetgin 13/3 (2021) 2800-2818}

Ergüven, M. H. (2010). Wellness Turizmi: Toplumsal Nedenleri ve Geleceğine Bir Bakış. N.Kozak ve M.Kozak(Ed.), I. Disiplinlerarası Turizm Araştırmaları Kongresi Bildiriler Kitabı içinde (587-599 ss.). Ankara: Detay.

Ergüven, M. H. (2020). SPA: Su ile gelen güzellik. Hiperlink: İstanbul

Filieri, R. ve McLea, F.(2014).E-WOM and Accommodation: An Analysis of the Factors That Influence Travelers' Adoption of Information from Online Reviews. Journal of Travel Research ,53(1), 44-57.

Giritlioğlu, İ., Jones, E. ve Avcıkurt, C.(2014). Measuring food and beverage service quality in spa hotels:A case study in Balıkesir Turkey. International Journal of Contemporary Hospitality Management, 26(2), 183204.

Goyette, I., Ricard,L., Bergeron,J. ve Marticotte,F.(2010).e-WOM scale: Word-of-mouth measurement scale for e-services context, Canadian Journal of Administrative Sciences - Revue Canadienne des Sciences de 1 Administration, 27 (1), 5-23.

Gökkaya, S. ve Türker, N.(2018).İ̧s Motibasyonu ile İş Tatmini Üzerine Otel İşletmelerinde Karşılaştırmalı Bir Araştırma.İktisadi İdari ve Siyasal Araştırmalar Dergisi, 3(5), 12-28.

Gürbüz, E. ve Ormankıran, G. A. (2020). Evaluation of Customer Comments and Complaints about Hotel Businesses. Journal of Applied Tourism Research, 1 (1), 17-32.

Gürbüz,S. ve Şahin,F. (2018). Sosyal Bilimlerde Araştırma Yöntemleri.Ankara: Seçkin Yayıncılık

Hamzaçebi, A.B. ve Yozgat, U.(2019). Turizm Sektöründe Algı Yönetiminin Rolü. International Journal of Management and Administration, 3(5), 51-65.

Hennig-Thurau, T., Gwinner,K. P., Walsh, G. ve Gremler, D. D. (2004), Electronic Word-of-Mouth Via Consumer-Opinion Platforms: What Motivates Consumers to Articulate Themselves on the Internet, Journal of Interactive Marketing, 18(1), 38-52.

ISPA (2021). Spa goers. [URL: https://experienceispa.com/resources/spa-goers] (Erişim Tarihi: 15.05.2021)

Joffe, H. ve Yardley, L. (2004). Content and thematic analysis. D.F. Marks ve L.Yardley (Ed.), Research methods for clinical and health psychology içinde (56-68 ss.). Thousand Oaks, CA: Sage Publications.

Kaya, A. ve Kalyoncu, M. (2020). Sağlık Temalı Özel İlgi Turizmi. C.Işsk(Ed.), Özel İlgi Turizmi içinde (26-53 ss.). Eskişehir: Anadolu Üniversitesi Açıöğretim Fakültesi Yayınları.

Kızllırmak, İ., Alrawadieh, Z. ve Aghayeva, S.(2014).Content Analysis of Online Travel Reviews on Eastern Black Sea Region's Hotel Businesses. GUEJISS, 6 (14), 110-121.

Küçükusta, D., Pang, L. ve Chui, S. (2013). Inbound Travelers' Selection Criteria for Hotel Spas in Hong Kong. Journal of Travel \& Tourism Marketing, 30(6), 557-576.

Kwon, J. M., Bae, J. I. ve Phelan, K. (2011). Online Consumer Herding Behaviors in the Hotel Industry. Paper presented at 16th Graduate Students Research Conference, Houston, Texas, 08.01.2011

Li, H., Ye,Q. ve Law,R. (2013). Determinants of Customer Satisfaction in the Hotel Industry: An Application of Online Review Analysis. Asia Pacific Journal of Tourism Research, 18(7), 784-802.

Limberger, P. F., dos Anjos, F. A., de Souza Meira, J. V. Ve dos Anjos, S. J. G. (2014). Satisfaction in hospitality on TripAdvisor.com: An analysis of the correlation between evaluation criteria and overall satisfaction. Tourism \& Management Studies, 10(1), 58-64.

Litvin, S.W., Goldsmith, R.E. ve Pan,B. (2008).Electronic word-of-mouth in hospitality and tourism management.Tourism Management, 29(3), 458-468.

Lurie, N.H. (2004).Decision Making İn İnformation-Rich Environments: The Role Of İnformation Structure. J. Consum. Res, 30, 473-486.

Miguens, J., Baggio, R. \& Costa, C. (2008). Social media and tourism destinations: Tripadvisor case study. Paper presented at the Advances in Tourism Research, Aveiro, Portugal, 26-28 May 2008.

Mak, A.H.N., Wong, K.F.K. ve Chang R.C.Y. (2009).Health or Self-indulgence? The Motivations and Characteristics of Spa-goers. Internatıonal Journal of Tourism Research, 11, 185-199. 


\section{H. Geranaz - D. Yetgin 13/3 (2021) 2800-2818}

O'Connor, P. (2010). Managing a Hotel's Image on TripAdvisor, Journal of Hospitality Marketing and Management, 19(7), 754-772.

Özbek, D. ve Özbek, T. (2008). Jeotermal Kaynakların Sağllk ve Termal Turizme Entegrasyonu. Jeoloji Mühendisleri Odası Haber Bülteni. 2(3), 99-113.

Ramos V. ve Untong A. (2016) Spa Tourism. Jafari, J ve Xiao, H. (Ed.), Encyclopedia of Tourism Cham: Springer, 886-888.

Reyes-Menendez, A., Saura, J. R ve Martinez-Navalon, J. G.(2019).The Impact of e-WOM on Hotels Management Reputation: Exploring TripAdvisor Review Credibility With the ELM Model.EEE Access, 7, 68868-68877.

Sevinç, F. (2021). Sosyal Medya Kullanıcılarının Deneyim Turizmi Serüveni. 1 Uluslararası Türk Dünyası Turizm Araştırmaları Dergisi, 6(1), 1-16.

Sezen Doğancili, O., Karaçar,E., Ak, S. (2019). Göller Bölgesi'nde Yer Alan Otel İşletmelerinin Tripadvisor'daki Tüketici Değerlendirmeleri Üzerine Bir Araştırma . Uluslararası Türk Dünyası Turizm Araştırmaları Dergisi , 4 (1) , 96-106.

Sparks, B.A. ve Browning,V. (2011).The impact of online reviews on hotel booking intentions and perception of trust. Tourism Management, 32(6), 1310-1323.

Statista .(2021). Tripadvisor - statistics \& facts. [URL:https://www.statista.com/topics/3443/tripadvisor/] (Erişim Tarihi:25.05.2021)

Stringam, B. B., ve Gerdes Jr, J. (2010). An Analysis of Word-of-Mouse Ratings and Guest Comments of Online Hotel Distribution Sites. Journal of Hospitality Marketing \& Management, 19(7), 773-796.

Snehasish, B. ve Chua, A.Y.K.(2016).In Search of Patterns Among Travellers' Hotel Ratings in TripAdvisor. Tourism Management, 53, 125-131.

Şahin, H , Çolakoğlu, O , Kılıçdere, S ve Atay, H.(2020). Kuşadası'nda Bulunan 5 Yıldızlı Otel İşletmelerine Yönelik Yapılan Sosyal Medya Yorumlarının İncelenmesi. Tourism and Recreation, Ek Sayı, 103-110.

Sarışık, M. ve Özbay, G.(2012). Elektronik Ağızdan Ağıza İletişim ve Turizm Endüstrisindeki Uygulamalara İlişkin Bir Yazın İncelemesi. Uluslararası Yönetim İktisat ve İşletme Dergisi, 8(16), 1-22.

Thorsteinsdottir, K. (2005).The State of The European Hotel Spa Sector.Journal of Retail \& Leisure Property , 4 , 272-277.

Thurmond, V.A. (2001).The Point of Triangulation. Journal of Nursing Scholarship, 33(3), 253-25.

Trihas, N ve Konstantarou, A.(2016).Spa-goers' Characteristics, Motivations, Preferences and Perceptions: Evidence from Elounda, Crete. Almatourism - Journal of Tourism, Culture and Territorial Development, 7(14), 106-127.

Tontuş, H. Ö. (2019). “Sağlık Turizmi Nedir?”, [URL: http://www.saturk. gov.tr] (Erişim Tarihi:25.05.2021)

Van Tubergen, A. ve Van Der Linden, S. (2002). "A Brief History of SPA Therapy", Annals of the Rheumatic Diseases, 61(3), 273-275.

Vermeulen, I.E. ve Seegers ,D.(2009).Tried and Tested: The Impact of Online Hotel Reviews On Consumer Consideration. Tourism Management, 30(1), 123-127.

Westbrook, R.A. (1987).Product/consumption-based affective responses and postpurchase processes. Journal of Marketing Research, 24 (3), 258-270.

Yeşilyurt, H., Çalışkan, C. ve Okat, Ç. (2020). Potansiyel Turizm Destinasyonlarında Bulunan Otellerle İlgili E-Şikâyetlerin Coğrafi Bakışla Değerlendirilmesi: Adıyaman Örneği. Türk Turizm Araştırmaları Dergisi, 4(3), 2003-2017.

Yetgin, D., Çalık, A.Ö. ve Çiftci, G. (2018). Turist Rehberlerine Yönelik Sanal Şikâyetler: www.sikayetvar.com örneği. N.Hacıoğlu, C.Avcıkurt, A.Kılıç ve H.Ulusoy Yıldırım(Ed.), Turist Rehberliği Üzerine Güncel Araştırmalar içinde (622-637 ss.).Ankara: Detay Yayıncilık.

Yetgin, D., Keküç, M. ve Şayin, M. (2020). Restoranlara Yönelik Tripadvisor Yorumlarının İçerik Analizi Yöntemi İle Değerlendirilmesi: İstanbul Örneği. Journal of Tourism and Gastronomy Studies, 8(3), 20902109.

Yıldırım, A. ve Şimşek, H. (2018). Sosyal Bilimlerde Nitel Araştırma Yöntemleri, Ankara: Seçkin Yayıncılık. 


\section{H. Geranaz - D. Yetgin 13/3 (2021) 2800-2818}

Yılmaz, E.S. (2019). Tripadvisor Seyahat Blog Sitesinde Yapılan Yorumlara Göre, Otel Tercihlerine Etki Eden Kriterlerin Analizi, (Yayımlanmamış Doktora Tezi), Gaziantep Üniversitesi, Sosyal Bilimler Enstitüsü, İşletme Anabilim Dalı, Gaziantep.

Zhang, Y. (2018). Research on Hotel Industry Personalized Service from the Perspective of Experience Economy, Advances in Social Science, Education and Humanities Research, 193, 111-114. 